See Article page 28.

\section{Commentary: Tricuspidization of a quadricuspid aortic valve: Different valve, same repair}

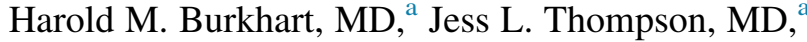 \\ and Arshid Mir, $\mathrm{MD}^{\mathrm{b}}$
}

Quadricuspid aortic valve is a rare anomaly with a frequency of $0.006 \%$. If patients present clinically, it is typically in the fourth or fifth decade of life with aortic valve insufficiency. ${ }^{1}$ Approximately $20 \%$ will require surgical correction, accounting for $0.5 \%$ to $1.0 \%$ of aortic valve operations for insufficiency. ${ }^{1,2}$ Of note, quadricuspid truncal valves are commonly seen in congenital cardiac disease, being present in at least $20 \%$ of patients with truncus arteriosus. ${ }^{3}$ The predominant mode of presentation in these patients is insufficiency. Most of these patients have uniform or nodular thickening with dysplastic cusps and unequal cusp size. The etiology of the insufficiency is a combination of restricted leaflet motion from dysplastic cusps, excessive motion due to leaflet prolapse, and cusp tears. ${ }^{4}$

In this issue of the Journal, Perrier and colleagues ${ }^{5}$ describe a case of a quadricuspid aortic valve that was repaired. The 39-year-old patient was symptomatic because of severe insufficiency of the valve from a central coaptation defect. The aortic valve had 4 cusps of equivalent size. Upon inspection, the right-sided, more posterior accessory noncoronary cusp was prolapsing. The repair technique they used was tricuspidization via sinus resection and annular plication. The root was then reimplanted using a 26-mm prosthesis. Four months after the operation, the patient was asymptomatic, his ejection fraction had improved from $50 \%$ to $60 \%$, and there was only trivial aortic insufficiency. The authors should be congratulated on an excellent

\footnotetext{
From the ${ }^{\mathrm{a}}$ Division of Cardiovascular and Thoracic Surgery, University of Oklahoma Health Sciences Center, Oklahoma City, Okla; and ${ }^{\mathrm{b}}$ Section of Pediatric Cardiology, University of Oklahoma Health Sciences Center, Oklahoma City, Okla. Disclosures: Authors have nothing to disclose with regard to commercial support.

Received for publication Dec 6, 2019; accepted for publication Dec 12, 2019; available ahead of print Jan 28, 2020.

Address for reprints: Harold M. Burkhart, MD, Division of Cardiovascular and Thoracic Surgery, University of Oklahoma Health Sciences Center, PO Box 26901, WP-2230, Oklahoma City, OK 73105 (E-mail: Harold-burkhart@ouhsc. edu).

JTCVS Techniques 2020;1:32-3

2666-2507

Copyright (C 2020 The Author(s). Published by Elsevier Inc. on behalf of The American Association for Thoracic Surgery. This is an open access article under the CC BY-NC-ND license (http://creativecommons.org/licenses/by-nc-nd/4.0/).

https://doi.org/10.1016/j.xjtc.2020.01.002
}

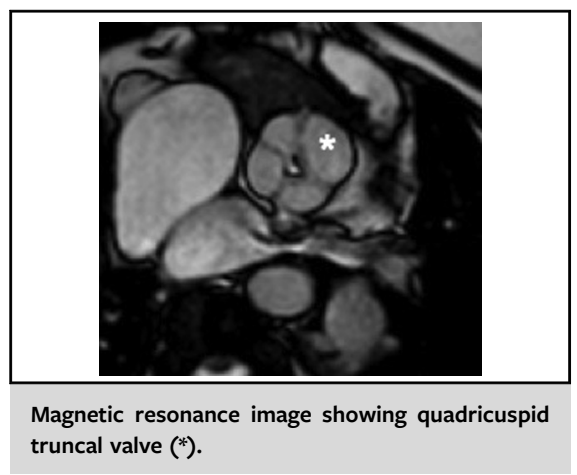

CENTRAL MESSAGE

Tricuspidization of a quadricus-

pid semilunar valve is a known

congenital cardiac technique

that may be successfully used in

the adult patient.

result with a complex operation. One of the strengths of the article is the inclusion of images and a video that beautifully illustrate the repair technique. In addition, using the leaflet to buttress the suture line is a novel modification.

Imamura and colleagues ${ }^{6}$ were the initial advocates of the annulovalvuloplasty technique of transforming a quadricuspid semilunar valve to a tricuspid valve. They reported successful tricuspidization of insufficient quadricuspid truncal valves in 3 neonates at the time of complete truncus arteriosus repair. Soon after, Mavroudis and Backer ${ }^{7}$ reported their experience with truncal valve remodeling. They reported truncal valve interventions in 8 patients, 3 of whom had leaflet excision and tricuspidization of an insufficient quadricuspid valve. In 2 of these patients, the leaflet excised involved a coronary sinus necessitating coronary artery reimplantation. The outcomes with this technique were excellent, leading them to support the use of this technique when possible.

The annulovalvuloplasty technique of reducing a quadricuspid semilunar valve to a tricuspid valve effectively treats valvular insufficiency. The procedure allows for downsizing and remodeling the annulus while minimizing leaflet sutures. This proven truncal valve technique appears to be an effective strategy in adult patients presenting with aortic valve insufficiency.

\section{References}

1. Tsang MY, Abudiab MM, Ammash NM, Naqvi TZ, Edwards WD, Nkomo VT, et al. Quadricuspid aortic valve: characteristics, associated structural cardiovascular abnormalities, and clinical outcomes. Circulation. 2016;133:312-9. 
2. Yuan SM. Quadricuspid aortic valve: a comprehensive review. Braz J Cardiovasc Surg. 2016;31:454-60.

3. Naimo PS, Fricke TA, Yong MS, d'Udekem Y, Kelly A, Radford DJ, et al. Outcomes of truncus arteriosus repair in children: 35 years of experience from a single institution. Semin Thorac Cardiovasc Surg. 2016;28:500-11.

4. Naimo PS, Fricke TA, d'Udekem Y, Brink J, Weintraub RG, Brizard CP, et al. Impact of truncal valve surgery on the outcomes of the truncus arteriosus repair. Eur J Cardiothorac Surg. 2018;54:524-31.
5. Perrier SL, Billaud P, Kindo M, Mazzucotelli JP. Quadricuspid aortic valve: surgical repair with aortic root reimplantation in an adult. J Thorac Cardiovasc Surg Tech. 2020;1:28-30.

6. Imamura M, Drummond-Webb JJ, Sarris GE, Mee RB. Improving early and intermediate results of truncus arteriosus repair: a new technique of truncal valve repair. Ann Thorac Surg. 1999;67:1142-6.

7. Mavroudis C, Backer CL. Surgical management of severe truncal insufficiency: experience with truncal valve remodeling techniques. Ann Thorac Surg. 2001; 72:396-400. 